\title{
UNA ELOCUENCIA EN CUESTIÓN, O EL ETHOS CONTEMPORÁNEO DEL POETA
}

\author{
Pere BALLART \\ Universidad Autónoma de Barcelona \\ El poeta es tanto más digno de elogio cuanto que alcanza las \\ virtudes del orador estando atado por el verso.
}

Marco Tulio Cicerón, El orador

Resumen: El principal objetivo de este ensayo es el análisis de la poesía lírica desde un punto de vista retórico. El poema es visto como un discurso persuasivo arriesgado, que pone a prueba la adopción de un ethos conveniente, y los numerosos ejemplos muestran la importancia de este elemento en el establecimiento de una complicidad con el lector.

Abstract: The main purpose of this essay is to study contemporary lyric poetry from a rhetoric point of view. The poem is seen here as a risky persuasive discourse in which is checked the good ethos of the poet, and the various examples show the importance of this element in the quest for the reader's agreement. 
Palabras clave: Retórica, Poesía lírica, Ethos, Persuasión.

Key words: Rhetoric, Lyric poetry, Ethos, Persuasion.

Me temo que no serán pocos los asiduos lectores de Signa que, apenas mediada la introducción de este artículo, opinen que al fin y al cabo, y dado el viaje que propone, tampoco hacían falta unas alforjas como las que ha escogido llevar a cuestas, en especial en su segunda parte. Pues de hecho lo que aquí va a defenderse no es otra cosa que la oportunidad de una aproximación de carácter retórico al género de la poesía lírica, que aquí estará representado por algunos ejemplos actuales, espigados de la producción de diversos autores españoles contemporáneos. Puede parecer, en efecto, muy poco original la apuesta a favor de un nuevo acercamiento de la vieja disciplina de la techné rhetoriké a ese paradigma de excelencia verbal que siempre ha supuesto la poesía; máxime cuando durante tantos siglos los lazos entre esos dos ámbitos del pensamiento y la creación han sido tan estrechos y mutuamente enriquecedores: ¿cuántas veces no se ha estimado que la mejor forma de explicar los peculiares mecanismos semánticos del poema era poniendo de relieve su excepcionalidad como lenguaje acusadamente figurativo? ¿Cuántas veces, a la inversa, no se creyó que la mejor ilustración de cualquier definición retórica cabía buscarla en los versos más escogidos de los autores líricos?

Es forzoso reconocer, sin embargo, que casi siempre que se ha acometido el análisis de los modos de significación de la poesía con el auxilio de un utillaje retórico, en éste los críticos han tendido a buscar sobre todo un instrumento que midiese con precisión el grado de singularidad estilística exhibido por un autor o un período de la historia literaria, y muy especialmente en su uso de figuras (por ejemplo la metáfora), en su concepción estructural del poema (por ejemplo en su engarce con una forma métrica como el soneto) o bien, algunas veces, en su actualización de una tópica fijada por su particular tradición (por ejemplo la amorosa). Dicho de otro modo: la mayoría de análisis retóricos de poesía suelen acentuar casi en exclusiva aquellos aspectos textuales que corresponden al dominio de su elocutio, frecuentan algo menos los problemas derivados de la dispositio del discurso, y sólo muy de tarde en tarde toman en 
consideración la inventio que ha podido estar en la base de la construcción del texto. Es entonces con relación a este concreto estado de cosas que el presente artículo puede creerse con algún derecho a estar postulando, aun desde la modestia del simple esbozo que pretende ser, un cierto sesgo original en el terreno de la retórica de la lírica. Porque la hipótesis de que quiero hacer partícipe al lector en las siguientes páginas es que sólo desde una perspectiva teórica como la que ya desde Protágoras y Gorgias se ha ocupado de dirimir las causas y procedimientos de la persuasión — sólo, pues, desde la noble disciplina de la Retórica-, se puede comprender la sin par dificultad creativa que acucia hoy al género de la poesía lírica y a sus cultivadores, tanto en lo que respecta a la ejecución formal de sus composiciones (en su determinación de un tema, una anécdota, una voz y un tono) como muy particularmente a su precaria comunicabilidad (en su apelación a un lector de especial exigencia).

Mi idea, en efecto, es que el problema al que se enfrenta el poeta de nuestro tiempo, es decir, el poeta cuya consideración social y literaria ha pasado a estar directamente condicionada por las circunstancias que la modernidad conlleva, tiene una inequívoca raíz retórica, por cuanto afecta al modo en que la voz que habla en el poema consigue (o no) erigirse en instancia significativa y llegar a establecer (o no) una potencial comunicación con el conjunto de sus lectores. Una voz $-\mathrm{y}$ aquí reside el verdadero quid de nuestro asunto- cuyo crédito ha ido menguando a lo largo de los dos últimos siglos y que ha llegado a estar mucho más en tela de juicio que aquellas que aciertan a avalar cualquier otro discurso, incluso dentro de la misma literatura (véase, por ejemplo, lo que ocurre con las ficciones narrativas, donde nada cuestiona la autoridad de que por principio goza el narrador, excepción hecha, claro está, de aquellos casos en los que dicha autoridad es eventualmente socavada como un ingrediente más de la propia intención artística del relato). Desde que en 1857 el yo poético de Las flores del mal pensó en dirigirse a su destinatario con aquel célebre «-Hypocrite lecteur mon semblable - mon frère!» hasta hoy mismo, la poesía escrita en Occidente ha puesto en el centro de sus intereses (a diferencia de centurias anteriores, para las que el tema hubiera sido irrelevante, por no ser siquiera concebible en tanto que problema) la difícil complicidad por la que puedan todavía unirse poeta y público aunque no sea más que en el momentáneo encuentro que supone la lectura del poema. «En la retórica —escribe Walter Nash- existe siempre un elemento de complicidad; puede que sea grandilocuente, o encantadora, o forzada, o bien oblicua, pero al margen de cuál sea su 
carácter, lo que busca denodadamente es implicar a un cómplice en sus planes» (1989: 1). Es precisamente de esa voluntad de implicación de lo que quiero tratar aquí, y, como se puede comprender, su efectiva materialización en el poema no responde únicamente a una estrategia que tenga que ver sólo con el uso de unas determinadas figuras de dicción, o de pensamiento, o con una más o menos convencional representación de la realidad. Se relaciona más bien con aquel concepto fundamental de los retóricos clásicos al que se refieren como $\eta$ $\theta$ os (ethos) y que, por decirlo con la ayuda de la fórmula más simple de todas, la usada por Aristóteles (1356a), designa «el carácter del que habla». Su incidencia en la persuasión del auditorio, como se sabe, siempre fue subrayada de manera notoria, y su efecto, reputado como en absoluto inferior al que pueden alcanzar por su lado el pathos y su intento de percutir emotivamente el ánimo del receptor, o por supuesto el logos, en su racional organización de los argumentos lógicos del caso. Levantar un perfil de confianza, encontrar una voz segura y firme, construir, en definitiva, una identidad poética capaz de asumir lo que los versos declaran..., tal es la cifra hoy del éxito comunicativo de un poema, que descansa más en un componente de adecuación, verosimilitud y credibilidad, esto es, de persuasión, que en cualquier supuesto expresivo que haga de la efusión sentimental o de la imaginación visionaria el puntal simbólico del poema. Es por consiguiente del problema del ethos lírico, y de su concreción real en la poesía española de los últimos años, que aquí se va a discutir, pero no sería oportuno empezar a hacerlo sin antes parar mientes en el hecho de que el conflicto que rodea su difícil estatuto actual, la crisis de la que es objeto, tienen su origen en circunstancias que comprometen tanto la naturaleza genérica como la trayectoria histórica de lo que conocemos como poesía lírica. Ocupémonos un momento a continuación, muy a grandes rasgos, de unas y otras.

Es unánime el reconocimiento de que la poesía lírica es el género que comunica una mayor y más viva impresión de inmediatez en la expresión de las emociones, y ello a pesar de que, podemos decir que en la misma proporción, es el género por antonomasia de la elipsis, el más huidizo y oblicuo, el más reacio a explicar cualquier cosa que exceda, por obvia o por superflua, su radical pureza. Su alejamiento de las convencionales formas de significación prosaica es un argumento mil veces invocado cuando se la pretende definir. En general, diríamos, el poema lírico supone una irrupción momentánea en la conciencia de un yo que, por supuesto, no atiende sino al movimiento interior de sus percepciones, ideas y sentimientos. Es lo que una 
explicación famosa, de mucho predicamento en la crítica anglosajona, la del filósofo Stuart Mill, pretendía subrayar cuando al género de la oratoria, el discurso que escuchamos de manera ostensible e inequívoca, oponía diametralmente el género de la poesía, en el cual nuestra escucha es, por así decir, fortuita. Según eso, el poema es un discurso que oímos como al acaso, por casualidad (overheard), y no hace falta insistir en la repercusión que ese supuesto fundamental llega a tener en la concepción misma de la pieza: a diferencia del orador, que sabe y tiene presente en todo momento al destinatario de sus palabras, el poeta «desconoce» que está siendo escuchado; de ahí su parquedad, su efusión, sus licencias. No está mal como recurso: en ese dar la espalda al público, tan cercano al del actor, que no puede revelar su conciencia (si aspira a actuar convincentemente) de que tiene ante sí una platea llena, podemos explicarnos cientos de composiciones de la más genuina poesía lírica. Ahora bien: sería un error perder de vista que ese ajuste mental no es otra cosa —no es menos, pero tampoco más— que una oportunísima convención. Y tal vez a este propósito lo mejor sea recordar unas consideraciones que Jaime Gil de Biedma vertía en unas páginas de su Retrato del artista en 1956, en lo que constituye una digresión de un vuelo teórico indiscutible:

Cuando yo hablo o escribo una carta, el destinatario de mi actividad expresiva es alguien determinado con respecto a mí - aunque no sepa su nombre, aunque no le vea, aunque no le conozca - dentro de una situación mía que es previa a lo que expreso. Pero cuando escribo un poema, sé que el destinatario de mi actividad es el lector: alguien que sólo se determinará dentro de una situación de hecho, el acto de lectura, que es posterior a mi expresión. Un poema es una letra a la vista, sin plazo fijo de vencimiento.

Esto explica el porqué y el para qué de las convenciones literarias. Mi manera de expresarme viene a la vez condicionada por aquello que quiero expresar y por aquel a quien quiero expresárselo. ¿Qué hacer, cuando lo que determina al destinatario, lo que le sitúa dentro del juego de referencias que es mi situación de hecho, consiste precisamente en el hecho de que está indeterminado con respecto a ella? Las convenciones literarias, los géneros, permiten a poeta y lector situarse previamente en una tierra de nadie, convertirse en el poeta y el lector, o sea, en los dos términos formales de toda relación literaria. El lector queda sí formalmente determinado dentro de la situación de hecho del poeta — que es en gran parte, pero no totalmente, un hecho de la imaginación: una composición de lugar, según la gran frase de san Ignacio de 
Loyola. (1993: 186-187)

Por apurar del todo la brillante metáfora comercial de este pasaje, diremos que el poeta debe hacer cuanto le sea posible porque el importe material de esa letra a la vista sea muy alto, y porque nada haga sospechar que el cobro no será seguro y satisfactorio. Con todo ello quiero decir que aun en el caso en que el poeta, por el carácter meditativo del poema, deba aparentar que estima que nadie oye sus palabras, en realidad no debe ni siquiera un momento dejar de sopesar el efecto que éstas podrán estar causando en sus lectores; no debe olvidarse de poner en juego todo aquello que haga que su voz parezca mejor timbrada, más sincera, más creíble. Si al respecto pedimos opinión a los retóricos, no nos faltarán desde luego testimonios de interés. Por ejemplo el de Isócrates cuando, en su discurso Sobre el cambio de fortunas (Antídosis), recordaba: «¿Quién ignora que los discursos parecen más verídicos si son pronunciados por personas bien consideradas que por gente desacreditada, y que puede ofrecer más confianza una vida que un discurso?» (1980: 145-146). Claro está que, si pensamos en el orden autónomo de las obras literarias, y en especial en su condición de comunicaciones diferidas, que tan bien explicaba antes Jaime Gil, habremos de abrazar en cambio el criterio de Aristóteles, para quien «el carácter lleva consigo la prueba principal» siempre que «el discurso se dice de tal manera que hace digno de fe a quien lo dice» (1356a), lo que deja claro que deben ser las propias palabras las que irradien por sí mismas ese favorable aspecto. Un retórico contemporáneo como es Edward Corbett comparte ese mismo parecer:

Nótese que es el habla misma lo que debe crear dicha impresión [una atracción de carácter ético (ethical appeal)]. De modo que una persona totalmente desconocida de la audiencia (y éste es a menudo el caso cuando escuchamos una declaración o leemos un artículo en un periódico), puede llegar a inspirar ese tipo de confianza simplemente en virtud de sus palabras. Hay gente, por supuesto, que ya cuenta con una reputación que el auditorio conoce, y esa reputación, si es buena, lo predispondrá favorablemente hacia ella antes incluso de que diga una sola palabra. En última instancia, no obstante, es el discurso mismo el que debe establecer o mantener la atracción ética, puesto que lo que una persona dice en un discurso determinado podría debilitar o destruir hasta la mejor reputación previamente establecida. (1990: 80-81. La traducción es mía).

Traducido así a términos retóricos, el problema, por fin, deviene meridiano: ¿cómo puede el poeta dotar a sus palabras, que no sabe quién acabará escuchando, de un permanente atractivo ético? Una de las mejores respuestas que han podido darse a la 
cuestión, a mi entender, es la que acertó a ofrecer Juan Ferraté en su memorable Dinámica de la poesía, cuando la trasladó muy apropiadamente a un territorio vecino, de idénticos contornos, que es el del problema del tono. Según el crítico catalán, las «simpatías y antipatías» del lector «no pueden tener por base más que la figura que dibuja el propio poema de una voz, una actitud, una situación y una experiencia humanas peculiares, afines o no, atractivas o no», y será esa figura lo que en definitiva debamos considerar si lo que se pretende calibrar es la «justeza de tono» del poema (1982: 359-360). Si el poeta aspira, pues, a que sus palabras se impongan al lector en ese tono justo, deberá considerar que dicho tono no puede ser sino «el tono de la experiencia real, el de las relaciones humanas reales, el de las actitudes del hombre viviente realmente en un mundo que él conoce y que se conoce, aunque no se lo formule, por todos; que se conoce aunque sólo sea por la soledad de todos» (364).

Acometido el problema esta vez desde su vertiente histórica, lo cierto es que no ofrece unos términos menos complejos e interesantes que si lo contemplamos desde su definición teórica, es decir, desde un planteamiento a la vez sincrónico y abstracto. La historia de la poesía lírica en Occidente es un largo y lento viaje - tal vez con retrocesos, pero sin pausas - desde una concepción por la que el poema es un mensaje que emite el portavoz de una comunidad y que promueve un reconocimiento colectivo, hasta llegar a otra, muy distinta, según la cual el texto emana de una irrepetible conciencia personal, sin apenas otro contacto con el mundo de sus contemporáneos como no sea el hecho de compartir un mismo idioma, que el poeta ya se encarga, por otra parte, de volver también en la medida de lo posible intransferible y privado. «Una de mis preocupaciones constantes - hace escribir Fernando Pessoa a su heterónimo Bernardo Soares, autor del Libro del desasosiego - es el comprender cómo es que otra gente existe, cómo es que hay almas que no sean la mía, conciencias extrañas a mi conciencia, que, por ser conciencia, me parece ser la única» (1986: 125). La confesión del extraordinario lírico portugués es indicativa de hasta qué punto la poesía europea del siglo pasado llegó a prescindir de todo destinatario. Un singular estudio de W. R. Johnson, The Idea of Lyric, demostró hace unos años hasta qué sorprendente punto, en ese discurrir del «nosotros» al «yo», la poesía europea fue sustituyendo a lo largo de su historia un tipo de poema siempre dirigido explícitamente a un receptor, ya fuera único o plural, por otro de carácter meditativo, con el inequívoco carácter de un puro soliloquio (1982: cap. 1). La poesía simbolista y su duradera influencia marcaron en 
dicho sentido un grado máximo en la tendencia a la «monodia», mientras que la última centuria puede decirse que ha estado caracterizada por la variedad de propuestas para intentar recuperar ese contacto perdido con la distante realidad de sus lectores (Hamburger: 1991). No hace falta decir que ello ha redundado en beneficio de una renovada preocupación por hacer que el poema sea dicho por una voz adecuada, digna de crédito; en palabras de Ferraté, del mismo ensayo antes citado, «el canto del poeta parece deber aproximarse cada vez más (...) al habla humana reflexiva y atenta a identificarse con las demás voces humanas; cada vez más se acentúa en la poesía el tránsito de la monodia al monólogo» (1982: 364). Tal vez ninguna otra reflexión resuma mejor y en menor espacio la auténtica dimensión del problema que la que Antonio Machado se hacía por boca de Juan de Mairena, no por casualidad en el marco de una de sus impagables lecciones de Retórica: «Antes de escribir un poema — decía Mairena a sus alumnos - conviene imaginar el poeta capaz de escribirlo» (1989: 1993).

Habida cuenta, por consiguiente, del especialísimo estatuto de que sus convenciones genéricas y la misma evolución de la historia literaria han acabado por dotar a la poesía, no parece descabellado argüir que si ésta en nuestros días todavía aspira a trascender lo meramente privado de la experiencia creativa en que tiene su origen, por fuerza deberá considerar los modos en que su mensaje pueda hallar eco en la inteligencia del lector, de un lector que el signo de los tiempos ha hecho, por cierto, bienintencionado a la par que exigente, esforzado y curioso pero, con todo, de paciencia no infinita. Dichos modos no son, a mi entender, otros que los que nuestros clásicos tratados definen bajo aquellos apartados que se refieren al ethos. Es Cicerón, tal vez, quien vaya más allá, y en textos como el que ha servido de epígrafe a este artículo, declara su opinión de que caben exigírsele al poeta idénticas virtudes que las que puedan adornar a cualquier otro orador, pues en el fondo su cometido es común (1967a: 27). La tesis del autor de las Catilinarias, en efecto, es que «el poeta se parece mucho al orador, aunque es más ceñido en los números, más libre en las palabras, pero muy semejante y casi igual en el género de ornatos, así como en no tener materia definida ni circunscrita fuera de la cual no le sea lícito extenderse con facilidad y abundancia» (1967: 22). Mi propuesta es por lo tanto que hagamos nuestra la opinión de tan fino conocedor del arte oratoria para así ver, procediendo en la dirección contraria, qué atributos éticos de cuantos suelen ser recomendables para el orador en general dan 
también algún provecho al ser aplicados a la concreta tarea persuasiva que entablan en sus textos los poetas.

Prudencia, virtud y benevolencia, son, si seguimos el dictado de Aristóteles (Retórica, 1378a), las cualidades que todo buen orador debe idealmente reunir, si lo que pretende es que el discurso haga por si mismo digno de fe a quien lo pronuncia (1356a). A ellas añade Cicerón otras dos que al hablar de poesía deberemos ponderar continuamente: el ingenio para conocer «la índole de aquellos ante quienes habla o ha de hablar» (1967: 53), y la facultad de no «alejarse del sentido común y del modo usual de hablar» (ibíd.: 11). Hablamos por tanto de una credibilidad basada, como se ve, en la satisfacción, por parte de un orador avisado, de las expectativas de antemano levantadas por su efectivo auditorio. Quien con mayor espacio y detalle analizó a la postre la cuestión fue Quintiliano, que en el sexto libro de su Institutio oratoria nos recuerda que la apariencia de honradez y de afabilidad es inseparable del orador eficaz, en el cual hasta la misma manera de hablar debe ser sosegada y suave, y evitar toda actitud arrogante, cuando menos de un tono engreído y altanero, pues basta con que hable «con propiedad, agradablemente, digno de ser creíble» [proprie, iucunde, credibiliter] (1999: 333). Es poco antes, al inicio del capítulo, donde Quintiliano, discutiendo la importancia de actuar sobre los afectos de la audiencia, hace una precisión capital para entender por qué en el poema será mucho más determinante la actitud desplegada por la voz poética que su escueta formulación lógica: si las pruebas, desde luego, hacen que los jueces «tengan como mejor nuestra causa», los afectos, en cambio, «otorgan que también lo quieran», de modo que la simpatía acaba imponiéndose sobre el juicio pues «ven ya lo que se enjuicia como si se tratara de cosa propia» (1999: 327).

Estas últimas consideraciones nos van a permitir saltar por encima de un lapso de muchos siglos y llegar hasta nuestros días, en los que un lúcido poeta norteamericano, Carl Dennis, ha escrito un excelente libro con el declarado propósito de acercar la retórica a la comprensión de la poesía moderna; su título no puede ser más explícito, Poetry as Persuasion (2001), ni menos discutible su proximidad a los puntos de vista expuestos por el retórico riojano. Dice por ejemplo Dennis (las traducciones son mías) a propósito del discurso poético: 
Lo que distingue a la retórica de la poesía de la retórica de la prosa discursiva [...] es que su argumento, en términos aristotélicos, descansa más sobre el ethos que sobre el logos, más sobre el carácter del hablante que sobre las pruebas lógicas. Para que un poema resulte convincente, la labor prioritaria del escritor es construir un hablante cuya compañía merezca la pena y que exhiba ciertas virtudes capaces de granjearse la atención simpática del lector. (2001: 2)

En idéntico sentido se orienta su concepción de lo comunicado por el poema, según él «una suma compleja de actitudes emocionales, éticas y estéticas, expresadas con la inmediatez y espontaneidad que experimentamos al escuchar la franca conversación de un amigo»(6), y asimismo su definición de los principios que confieren autoridad al ethos, en una brillante síntesis de lo postulado por los tratadistas clásicos:

\footnotetext{
¿Qué virtudes, pues, debe desplegar un hablante a fin de prestar autoridad a sus palabras? En mi opinión tres son las fundamentales: pasión, discriminación, e inclusividad. Quiere decirse que debe mostrar, primero, que se preocupa por lo que dice; segundo, que ha llegado a sus actuales opiniones no por ignorar las contrarias, sino sólo después de haberlas considerado y hallado insatisfactorias; y tercero, que es consciente de las implicaciones que llevan del tema que trata a otras posibles cuestiones. (17)
}

Era exactamente a este punto adonde me interesaba conducir la reflexión, porque desde ningún otro aspecto del problema apreciaremos mejor en qué medida es retórico el desafío expresivo que hoy tiene planteado cualquier poeta que se precie: es en estas consideraciones de Dennis - tan cercanas, por otra parte, al Aristóteles que nos recuerda que hace más honrado al orador el parecer honesto que la más precisa de las argumentaciones $(1418 b)$ - , donde resplandece la necesidad que todo poeta tiene hoy de trasladar a sus versos aquel «sentido de la realidad» (no hallo una mejor expresión), sin el cual el lector le tendrá por fatuo, por ingenuo o por dogmático. Cuáles sean los medios por los que ello pueda llegar a buen término, sin que por eso el poeta deba dimitir de su voluntad de dar una proyección lírica a la intimidad de su yo, es lo que en las siguientes páginas me va a complacer estudiar. En los ejemplos de los que me ocuparé, repitámoslo, mi propósito es detenerme muy en especial en la forma cómo sus diferentes autores se esfuerzan por «construir voces convincentes» (Dennis, 2001: 2). Cómo hacen, por tanto, para asegurar el contacto con el receptor y, sin dejar por ello de 
atender a sus emociones y pensamientos subjetivos, como acabo de decir, conseguir que éste se sienta concernido bien porque las cuestiones que son expuestas en el poema no sean al cabo de importe únicamente individual, o bien, aun en el menos optimista de los supuestos, por la actitud manifestada por el yo poético, quien, puesto a la tarea de dar razón de sus reacciones, lo hace desde una tesitura capaz de mover a simpatía. En los temas y su grado de alcance humano, pues, pero sobre todo en el tono, en la elección y control de una distancia desde la cual abordarlos, habrá que medir el mayor o menor acierto persuasivo de cada poema, su auténtico poder de implicación.

Sólo una última puntualización nos aparta aún de los ejemplos: seríamos nosotros quienes mostrásemos muy poco sentido de la realidad si no dejásemos constancia de que no toda la poesía que hoy se escribe comparte por igual la misma preocupación acerca de a quién se dirige la voz que habla en el poema. Los escritores que a fecha de hoy siguen haciendo suya una concepción de la poesía como la que fue defendida por el simbolismo, tanto en su modalidad visionaria como en la que abogaba por una extrema depuración formal del poema, ciertamente supeditan toda ulterior eficacia persuasiva de sus versos a algo que reputan como de mucha mayor importancia, y que tiene que ver con la excepcionalidad semántica y con el ahondamiento subjetivo de una enunciación solipsista, oracular, que si bien se mira es menos una confidencia que un cántico. A este propósito, y como es del dominio público, las polémicas han arreciado en las dos últimas décadas y a menudo se han apoyado en presupuestos notablemente estériles. Visto desde la retórica, el problema ofrece quizá un carácter algo más nítido, y puede ser bueno escuchar el parecer de Carl Dennis, para quien centrar el poema «en la exposición de la distancia entre el arte y la vida implica confinarse uno mismo a una forma menor de escritura, reducir la obra del escritor a un papel aleccionador. Significa volver la espalda a aquella oportunidad que el arte más ambicioso proporciona a sus receptores, esto es, la posibilidad de ver cuestionada y ensanchada la propia visión de la vida». Puesto que su testimonio es al cabo el de un poeta, por lo que puede serle achacada la imputación de convertirse en juez y parte, tal vez resulte más prudente cerrar este punto con una voz mucho menos sospechosa de veleidad lírica alguna: la del ilustre teórico de la argumentación Chaïm Perelman, cuando escribió que «quien hace vaticinios sin tomar en consideración las reacciones de quienes le escuchan, es considerado enseguida un iluminado, alguien que sólo atiende a 
sus demonios interiores, antes que una persona razonable que busca hacer compartibles sus propias convicciones» (1977: 29 ; la traducción es mía).

Vengamos, por fin, a lo concreto y hagámoslo estudiando en especial qué solución material suelen dar los poetas al problema de hacer incluyente su experiencia. Dado que la omnisciencia no resulta el mejor de sus haberes, el personaje poético debe ganarse nuestro respeto haciéndonos creer en su modestia, y ello está a su alcance bien objetivando y generalizando su emoción hasta hacerla de algún modo típica, bien dramatizando a lo largo del poema la presencia de su yo de modo que no quepa duda acerca de su conciencia de la realidad, de su capacidad de «discriminación», por decirlo como Dennis. Sea como sea, desde luego el dispositivo formal con una mayor incidencia sobre esa construcción del ethos, esto es, sobre una determinada personalización del discurso poético, es el juego sobre los pronombres que permiten identificar al responsable de sus enunciados. Su elección concreta, su mayor o menor recurrencia, la actualidad de su valor deíctico, regulan el grado de exteriorización de la conciencia del poeta $\mathrm{y}$, por consiguiente, las condiciones de posibilidad de un acercamiento efectivo al lector.

Aunque no son los de mayor frecuencia, hay casos en los que dicha personalización resulta diáfana y directa, de modo que su posible cuestionamiento no parece formar parte de las intenciones del autor. Basta recordar, por ejemplo, el inicio del poema «Espejo, dime», de Luis García Montero: «Déjame que responda, lector, a tus preguntas, / mirándote a los ojos, con amistad fingida, / porque esto es la poesía: dos soledades juntas / y una experiencia noble de contarnos la vida» (1997: 173), para apreciar el carácter inmediato de su apelación, su ostensible publicidad, que casi lo asemeja a lo que en otro contexto conocemos como carta abierta, de tan poderosa como es la ilusión de que los yo y tú del poema son precisamente los reales, el sujeto civil que lo escribió y el que ahora lo ha leído. En otras ocasiones, como sucede en el poema «Siesta», de Álvaro Salvador, el discurso alude tan explícitamente a su condición literaria (es decir, de texto premeditado para salir al encuentro emotivo de un lector) que el procedimiento parece por sí solo convertirse en transparente aval de cuanto sirve a expresar, acaba por funcionar como un blindaje, por así decir, de su sinceridad: «Si escribo estas palabras temo dar una imagen / de escritor que conoce su oficio y sus recursos, / temo no dar la talla, carnal, enamorada, / de un hombre que ha pisado el umbral de sus sueños» (1997: 17). Puede darse también que el poema sea enunciado 
desde una primera persona, pero del plural, con la que el yo poético nos agrupa a todos sus congéneres en una experiencia tan por encima de lo individual que se dibuja ya como patrimonio de nuestra condición humana, como en estos versos del poema «El combate por la luz», de Carlos Marzal: «A fuerza de costumbre, hemos dado en creer / que es un merecimiento, cada día, / que el día se levante en claridad / y que se ofrezca límpido a los ojos, / para que la mirada le entregue un orden propio, / distinto a los demás, y lo convierta / en nuestra inadvertida obra de arte» (2001: 21). Finalmente, unos versos de Vicente Gallego pueden servir para recordarnos que la poesía cuenta siempre con la posibilidad de recuperar su dimensión más moralizadora y didáctica (que tan del gusto de los clásicos llegó a ser), a tenor de la cual un inconfundible «vosotros» consigue convertir a todo el mundo en un destinatario universal susceptible de ser aleccionado; los tomo de su poema «Ley de vida» (2002: 90): «Cuando os señale el dedo del azar, / de mercedes cargado y de benevolencia, / reparad en aquel que ha recibido / la visita del ángel justiciero; / sostened en la noche la mirada, / y aprended en su luto a redoblar, / furiosos, / vuestra danza en honor de la buena ventura».

Como ya he dicho antes, sin embargo, los poemas planteados desde supuestos tan, digámoslo así, «puros» y poco equívocos a la hora de fijar el marco de su enunciación no son tan usuales ni tal vez tan interesantes - en su concreta relación con los artificios con que es impostada la voz para hacer sus modulaciones atractivas, quiero decir - como aquellos otros, mucho menos obvios, que se proponen tomar la distancia y una implícita controversia de orden moral como los principales ingredientes de su propuesta expresiva. Empezaremos con un poema del malagueño José Antonio Mesa Toré, de su libro de 1998 La primavera nórdica (1999: 17), donde la mirada crítica que el poeta se dirige a sí mismo facilita extraordinariamente el crédito que es posible conceder a sus palabras:

\section{LA ALEGRE MILITANCIA}

La mañana en que un muerto salió de nuestra casa yo seguí respirando alegremente.

¿Acaso el aire estaba más pasivo que de costumbre?

Yo seguí creciendo sin esfuerzo en el libro de familia, disfrutando del sol a pesar de las gafas oscuras, 


\author{
de la pía corbata lastimera \\ en la orfandad del pecho. \\ Yo seguí con la vista \\ puesta en los firmes culos allegados, \\ en escotes de pésame y juventud risueña. \\ Me avergüenza pensarlo. \\ Pero el dolor jamás hará campaña \\ del lado de la muerte. \\ La mañana en que un muerto sale de nuestro tiempo, \\ es la vida tan viva, tan sol sobre el tejado, \\ es la vida, tan puta \\ y diplomática, \\ quien gana más adeptos.
}

Es — una vez más - en el espacio en el que lindan las actitudes sociales con el singular desarrollo de una estricta historia personal donde se cifra el éxito comunicativo del poema, y un buen síntoma de que estos versos de Mesa Toré circulan por esa región fronteriza es la alternancia con que saltan del «nosotros» (vv. 1 y 15) al «yo» (vv. 2-12). Como se explica en el excelente Rhetoric. The Wit of Persuasion, de Walter Nash, un exordio que fortalezca el sentimiento por parte del auditorio de que el orador pertenece a su misma comunidad, a su grupo, rinde siempre resultados positivos, y suele ser el uso del «nosotros», precisamente, el mayor elemento identificador de una identidad e intereses comunes (1989: 9). La oscilación entre el pronombre singular y el plural en nuestro caso es comprensible, puesto que el tema que el poema aborda es el de la asunción de la muerte de alguien próximo, una asunción que, al margen del coste sentimental que pueda conllevar a título individual, siempre resulta problemática desde la evidencia de la universal indiferencia hacia esa pérdida, desde la perpleja confirmación de la manida frase según la cual «la vida sigue». El poema sabe predisponernos favorablemente hacia su hablante pues no esconde que aquel sentimiento que ha incoado verdaderamente el discurso es, en el fondo, la mala conciencia de alguien que reconoce que su dolor real no está a la altura ni siquiera de las convenciones impuestas por el luto (un hombre joven que no sabe resistirse a los reclamos sensuales con que la vida continua atrayéndole). La exposición que contienen 
los primeros doce versos no oculta tampoco su carácter de confesión en toda regla, de disculpa pronunciada desde el arrepentimiento por haber indecorosamente olvidado aquellos deberes que un deudo de verdad afligido no puede desatender. El sesgo de la segunda parte del poema, no obstante, relativiza la inevitable reprobación que suscitaba lo dicho en la primera. La crudeza con que el yo poético llega a la constatación de esa perseverancia con que la vida se afirma en toda hora y situación, «tan puta y diplomática», impresiona al lector, que intuye así que tal vez su reacción en esas mismas circunstancias no hubiese sido muy distinta. Una interesante asociación analógica, por la que vemos referida en términos de actividad política («campaña», «adeptos», «militancia») la adhesión a las causas de la vida o la muerte, termina de convencernos de que no hay otra elección posible, de que nadie dará su voto al duelo permanente que la muerte impondría.

Atinaba Quintiliano desde luego cuando escribía, en el mismo pasaje de su libro sexto que antes citábamos, que nos mueve a ser benevolentes el ver que alguien pide indulgencia por aquello que cometió en su juventud - como hemos visto exactamente en el poema anterior-, y que en semejantes contextos se revela muy útil el recurso a la ironía, con su disimulación y sus sobreentendidos, de sentido diverso al aparente (1999: 331). Podemos confirmarlo del todo con el auxilio de la siguiente composición, incluida en el libro Volverlo a intentar, del año 1989 (1997: 133), del poeta sevillano Javier Salvago:

\section{LA LUCHA POR LA VIDA}

Presiento que no soy el mejor yo

de todos los que quise ser y he sido.

He conocido a otros más hermosos, mejor amantes y mejor vividos.

—Todos, sin excepción, mucho más jóvenes, prometedores y atractivos-.

No soy el mejor yo.

Pero, al menos, aguanto y sobrevivo.

Los demás, con sus sueños 
—cansados, derrotados, aburridos-,

fueron cayendo

uno tras otro en el camino.

Sin duda alguna, el mayor logro del poema está en la forma con que el yo saca un muy considerable partido de la ambigüedad con que se refiere a otras identidades diferentes de la propia, como hemos de ver enseguida. Su arranque, por otra parte, no podría convenir mejor al consabido propósito de la captatio benevolentiae: nada concede más crédito que la impresión de integridad de quien admite una falta, pues nos sentimos empujados a creer en aquél que no parece ganar nada, antes al contrario, con la emisión de su discurso. Javier Salvago no desconoce este extremo, y así ha hecho que el yo poético disipe toda presunción al confesar su conciencia de que no ha conseguido satisfacer sus ambiciones de otro tiempo. Esta impresión de humildad queda todavía más reforzada cuando sin sombra de envidia, más bien con una serena ecuanimidad, le oímos atribuir a «otros» una serie de cualidades de las que él se sabe carente - apostura, pasión, juventud - y cuya falta hay que presumir, pues, como la causa de que el antiguo proyecto de vida del personaje poético no se haya visto realizado, ni mucho menos, a la medida del deseo.

Sutilmente, sin embargo, el sentido del poema empieza a variar cuando ingresamos en la segunda estrofa. Tras la reiteración de su modestia, la voz poética propone una curiosa aceptación de eso que podríamos seguramente llamar mediocridad, y lo sorprendente es que sea su duración, la simple permanencia de ese estado, aquello que se aduce con el valor de un consuelo. De modo casi moralizador y bajo el aspecto de un súbito cambio de fortuna, el yo poético presenta ahora a esos tan bien dotados competidores en su paulatina decadencia y extinción. Es sólo al final cuando los lectores nos damos cuenta de que esas otras identidades no han tenido, a diferencia de lo que parecía, ninguna independencia respecto del poeta; de que esos «otros» (v. 3), «todos» (v. 5) y «demás» (v. 9) nunca dejaron de ser «yos», y que, en lugar de desempeñar el papel de unos despiadados rivales en el marco de una darwiniana struggle-for-life, su auténtica naturaleza es la de haber constituido diferentes estadios sucesivos de la personalidad del poeta, cuya fracasada desaparición («uno tras otro») deja solo y, por así decir, victorioso, al superviviente yo actual. La maniobra por parte de Salvago no puede ser más inteligente: la verdadera selección natural es aquella que nos hace ser lo 
que somos, llegar adonde hemos llegado. Esa final conformidad con nuestras vidas, una vez descartadas las ilusiones irresueltas y después de haber ironizado a costa del propio destino, no puede menos que derivar en un sentimiento de simpatía por parte del lector.

Como se puede comprobar, la posibilidad de que nos hagamos cargo de la verdadera situación del poeta a la hora de emitir su discurso deviene crucial si de nosotros se espera algún tipo de respuesta emotiva o, como mínimo, una recepción favorable, bien predispuesta. A ello puede ayudar que la pieza abunde en precisiones sobre cuál es exactamente esa situación, como es el caso de uno de los poemas que Roger Wolfe incluyó en 1996 en el volumen Mensajes en botellas rotas (Cano Ballesta, 2001: 267):

\author{
ALGO MÁS ÉPICO SIN DUDA \\ Las 00.30 y heme aquí \\ fumando hasta matarme \\ delante de una pantalla negra \\ con manchas de verde \\ embadurnándola.
}

\author{
Ahí fuera, en alguna \\ parte, en todas, \\ ensayos de cadáver \\ se arrastran hacia la mañana \\ en la estela de otra \\ noche vacía.
}

\title{
Me pregunto \\ qué hubiera dicho
}

\section{Homero.}

El poema (que en otro orden de cosas podría perfectamente funcionar con el valor de una poética) se orienta en su conjunto a la justificación de su especial carácter, tanto en lo temático como en su misma constitución verbal. La inmediatez con que el yo 
poético nos incumbe en su circunstancia (nótese, como ya anunciaba antes, la precisión realista con que se nos hace irrumpir en la impaciente medianoche del poeta tecleando ante su ordenador) hace que de algún modo debamos acompañarle en su particular percepción de las cosas, en su abatido estado de ánimo mientras contempla insomne el absurdo de una humanidad en tránsito rutinario hacia otro día de trabajo. En la brusquedad y el casi desprecio que el yo poético se dispensa a sí mismo y a la realidad que le rodea estamos llamados a ver el mejor síntoma de su confesada impotencia para hacer o decir otra cosa que la escrita. Ni siquiera Homero, parece decir el cierre del poema, podría conferir grandeza épica a situaciones y escenarios de una sordidez y desamparo como los que Wolfe ha decidido poner en las «botellas rotas» de sus composiciones, y así el poema se convierte, como hemos dicho, en una auténtica apología de esa concepción concreta de la lírica, junto con los datos y pruebas que han de valer nuestra aquiescencia al respecto.

De todas formas, sería erróneo suponer que sólo el poema que inscribe a su hablante en un entorno prolijamente descrito obtiene el beneficio de su asequible reconstitución. De hecho, un efecto de no menor alcance es el conseguido a partir del procedimiento diametralmente opuesto, que, como se verá, encarna muy bien la siguiente composición del vallisoletano Miguel Casado (ibíd.: 141):

CON FRECUENCIA, EL QUE MIRA

\section{Un río suele limitar su curso}

entre dos curvas: una y otra vez sigue

su mirada el sentido de las aguas

o lo remonta. Con frecuencia, surge

por la curva de arriba algún objeto, una rama que flota

cabeceando sus hojas brillantes, con flores que dispersan poco a poco

los pétalos; después desaparece

en la curva de abajo.

Entonces: bruscamente, como sobria

negación, sin anuncio, 


\author{
llega el conocimiento. \\ Pero el que mira el río ¿qué ha conocido? Ha visto que la rama \\ hacía siempre el mismo gesto y que era \\ siempre la misma rama; igual también \\ la superficie al conducirla. Estar \\ y no estar. No hay ningún cambio. Tal vez \\ lo que se observa cada día tenga \\ con la realidad \\ extraños vínculos, del mismo modo \\ que la apariencia de las cosas corre \\ diferente del tiempo.
}

Se entiende fácilmente, me parece, que la pieza sirva a la ilustración de cómo no necesariamente la personalización acusada del discurso ni su localización anecdótica invariables, por ejemplo, en algunos nombres de la «poesía de la experiencia», en la que desde luego no cabe contar a nuestro autor- han de ser vistas como expediente único de la implicación del receptor. Por el contrario, en este poema de Inventario (1987) asistimos a la absoluta objetivación de la anécdota, que de tan genérica deviene prácticamente ideal. Como quien postulase un caso ejemplar, el pretexto para la solución de un problema matemático o de un enigma de carácter lógico, el yo poético retrae por completo la efectiva situación de hecho en que tienen lugar sus palabras y en su sitio propone un suceso posible, una experiencia que a ningún lector le costará trabajo actualizar; primero, porque pertenece a un orden de conocimientos del que no carece ni un solo individuo de la especie, por decirlo rápido, y cuyo carácter atávico hubiera hecho superflua, si no ridícula, una mayor contextualización; segundo, porque la depuración del pretexto no priva al poeta de infundirle una vistosa realidad sensible (vv. 5-11). La consecuencia de todo ello es que el poema puede, en su segunda mitad, apuntar ya de lleno a su más profundo objetivo: el pausado fluir de la metáfora heraclitana conduce al poeta a una seria reflexión sobre la percepción y el conocimiento, y sobre sus límites comunes, $\mathrm{y}$, en último término, por si fuera poco, sobre el tiempo y su ilusoria detención, que a cada paso creemos operar con nuestro pensamiento. Así el poema logra al fin involucrar del todo al lector, aun a pesar de sus impersonales formas o, precisamente, si bien se mira, gracias a ellas: por una vez no ha decidido acercarse 
hasta él por el curso de la biografía, sino en todo caso por el de la antropología, si se me permite la figura.

Devolviendo la palabra a Quintiliano, me gustaría ahora recordar el paso en que, definiendo el preciso carácter que debe animar al ethos, el sabio calagurritano habla concretamente de una bondad basada en un sentimiento tierno y humano («blandum et humanum»). Un sentimiento, leemos, «cuya suma virtud, que expresar cabe, consiste en que todo parezca fluir del modo de ser de las cosas y de los hombres, y en que la actitud moral del orador resplandezca en su discurso y en cierta manera se haga conocer» (1997: 331). En mi opinión, es justo la clase de ternura, y de supremo tacto en la revelación de una personalidad moral, que exhibe un poema de Álvaro Salvador, de su libro El agua de noviembre, de 1985 (1997: 7-8)

\section{CANCIÓN DE MEDIODÍA}

Uno, a veces, quisiera no haber sido

ese joven feliz que en los guateques

se drogaba con la melancolía.

Porque uno, a veces, mira en la mañana

el rostro del dolor ante el espejo,

surcado por la angustia, castigado,

perdidos los encantos y el cabello

del solitario rostro: la tristeza

como una madreselva invadiéndolo todo.

Y uno siente en los huesos que hace frío,

que el brasero no enciende, que en la casa

penetra lentamente el viento de la tarde

como un azogue triste de soledad y desprecio.

¿Qué sola va la vida en ese mediodía

cuando sales al parque deambulando

por tu propio calor como una fiera! 
Qué sola irá la vida entre los bulevares

si apenas tu mirada puede ver los azules

presentes que la aurora dejó sobre los árboles

Porque uno, a veces, mira en la mañana

la lluvia del dolor por las aceras,

marcado por un rumbo, desterrado

perdidas la esperanza, la alegría

en los húmedos ojos: la tristeza

de una muchedumbre invadiéndolo todo.

Y uno siente, de pronto, la llamada,

la llamada en los labios, y en los ojos

penetra lentamente el sol de una sonrisa

como la dulce lámpara que salta al corazón.

Uno, entonces, quisiera ser de nuevo

ese joven feliz que en los guateques

se drogaba con la melancolía.

Es evidente que, en poesía, desde el mezzo del cammin dantesco hasta la «Hälfte des Lebens» de Hölderlin, la madurez que procura el mediodía de la vida le convierte en el momento idóneo para mirar atrás desde esa cima desde la que se dominan tanto las ilusiones de la aurora como, echando la vista al otro lado, las futuras sombras del crepúsculo. El poema de Salvador es ostensiblemente dicho desde esa edad en la que es posible ver la propia juventud con ojos distanciados y teñidos de ironía, y, en la medida en que ello supone por parte del yo poético (véanse los tres primeros versos) un saludable ejercicio de sinceridad, revelador de un incremento de experiencia, en esa crítica retrospección nos hallará cómplices a todos sus lectores. Pero la composición reserva una sorpresa cuyo efecto se encarga de llevar a la perfección la cuidada estructura del poema, de una simetría inesperada que obliga a considerar con detalle las relaciones entabladas entre sus distintas estrofas. Las cuatro primeras culminan un a modo de movimiento ascendente, en que el personaje poético parece razonar su presente 
soledad como una consecuencia de aquella pasividad del joven que antes fue, y que le ha llevado hoy a pasear su vacía y monótona existencia casi con el paso cansado de la pantera rilkeana (vv. 15-16). Sobre el entramado de hábiles paralelismos con que la segunda parte remeda a la primera, sin embargo, poco a poco apreciamos que el poeta ya no mira atrás sino adelante, para descubrir que nada va a paliar su triste situación. Y es por ello que, devanando al revés sus argumentos iniciales, el poema llega a su estrofa final, espejo de la primera, con una absoluta reversión de lo entonces expuesto. Pudo más la nostalgia que el sarcasmo y, a la suerte actual, parece preferible la de aquel adolescente tan ingenuo como contemplativo. La segura dispositio poética, que nos fuerza a deconstruir con el poeta su planteamiento de partida, así como el juego sutil sobre la impersonalidad del «uno» y el mucho más comprometedor «tú» de las estrofas centrales, cuarta y quinta (con su, por así decir, mecanismo de bisagra), son las bazas con que el ethos del poeta persigue nuestro consenso, para el que al cabo no habrá sido obstáculo alguno el minucioso artificio del poema. Notemos, también, en conclusión, cómo la voz ha evitado cuidadosamente cualquier aparición explícita del «yo» en ninguna de sus formas, que sin duda alguna hubieran llevado al poema (hágase la simple prueba de reescribirlo en primera persona) a sucumbir a una enojosa dicción sentimental.

Y ya que de pronombres hablamos, bueno será que contemplemos en esta misma dirección algún otro uso de los que pueden procurar un mayor control de la distancia respecto a experiencias por las que fácilmente el poeta podría dejarse sobornar, y dar al traste así con ese pudoroso equilibrio sin cuyo concurso el lector no está dispuesto a consentir cualquier confidencia. Veamos cuál es el que propone el granadino Antonio Jiménez Millán (2003: 37-38):

PRIMAVERA, 1976

Hace ya más de un siglo,

Baudelaire escribía en su diario:

«Buscar aventuras insólitas y horribles

en las capitales modernas». 


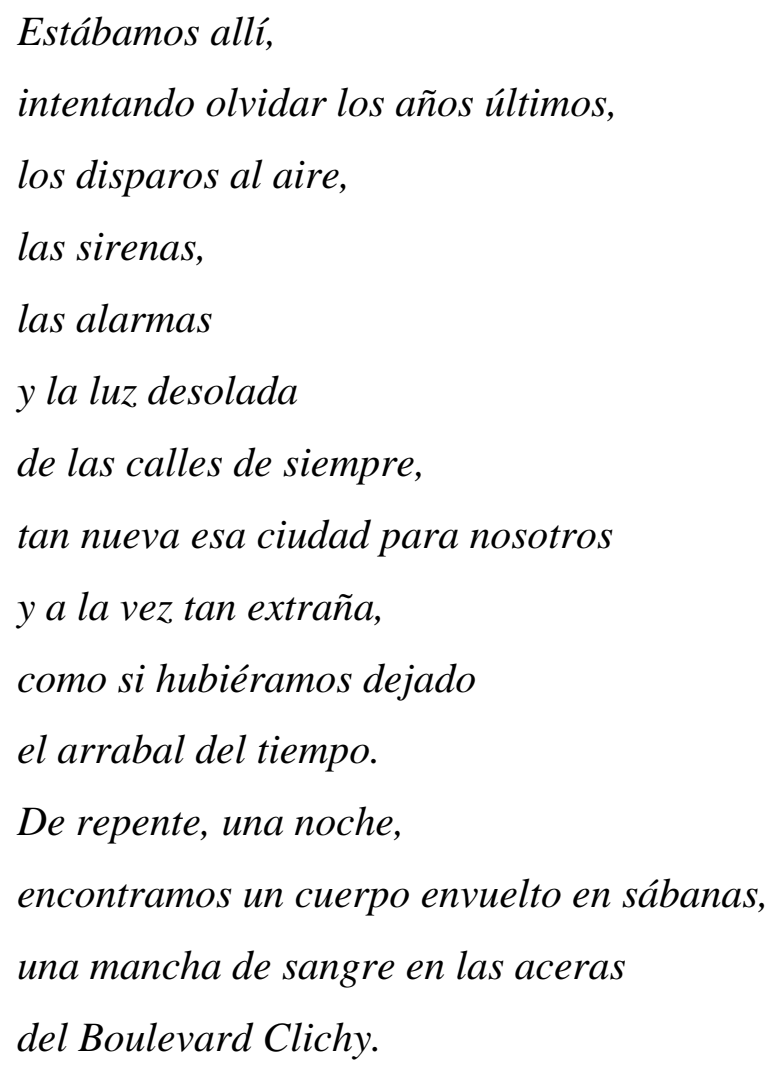

Y nadie se detuvo:

Era la indiferencia,

la muerte conocida.

\begin{abstract}
Acaso era
una versión distinta del infierno

o una aventura insólita,

excesiva tal vez para nosotros,

una gente tan joven,

llegada desde el limbo.
\end{abstract}

Como se puede apreciar, el arranque del poema (incluido en el reciente Inventario del desorden, de 2003) se acoge a un recurso tan propio de la prosa como infrecuente en el marco de las composiciones líricas: el llamado argumento de autoridad. La cita de Baudelaire, con su programática defensa de la vida metropolitana (según él escenario todavía posible de sucesos reveladores y transcendentes) encabeza el texto como un referente cuyo crédito el resto del poema se dedicará a reforzar, como 
justificando la vigencia de las palabras del autor de Le spleen de Paris. La implicación del lector, sin embargo, se va a operar tal como anunciábamos gracias al punto de vista escogido en la presentación de la anécdota. El «nosotros» que axialmente unifica toda la pieza resulta ser una argucia pronominal, por así decir, de un gran rendimiento significativo, por cuanto su polisemia autoriza la superposición de diversas lecturas del poema que, aunque próximas entre sí, no son completamente coincidentes. Para empezar, cabría atribuir a ese plural un valor puramente formulario, de modestia, propio de un yo lírico individual que pretendiese rebajar el carácter excepcional de su declaración, sabedor probablemente de que no se trata ni mucho menos de una experiencia única, lo que, de alguna forma, la vuelve casi anónima - como la de cualquiera de esos otros indiferentes transeúntes. También podemos, no obstante, leer de manera literal la marca de ese sujeto plural y entender que «nosotros, / una gente tan joven» denota que el yo no estuvo jamás solo en su deambular por la capital francesa. Con todo, una última consideración de los contenidos del poema nos llevará a la hipótesis seguramente más sólida, la de que el poema toma en cuenta una necesaria distancia en relación a su tema: la misma, más o menos, desde la que en su día Jaime Gil de Biedma concibió su conocido «París, postal del cielo», donde el personaje poético empezaba diciendo (y la cursiva es mía): «Ahora voy a contaros / como también yo estuve en París, y fui dichoso». El valor otorgado a la experiencia parisina está claramente en función, como en aquel poema, de su contraste respecto a la situación española desde la que dicha experiencia es vivida, una situación ciertamente convulsa (la del incierto primer año de transición a la democracia), pero de todo punto menos vertiginosa y cosmopolita que la de la urbe del norte. El poeta acierta al oponer simbólicamente ese «infierno» mundano al provinciano «limbo» del que se procede, y en la mezcla compleja de fascinación y temor que produce esa vida excesiva, predicha ya por Baudelaire, hay que ver desde luego un rasgo generacional, un estadio en la formación de la personalidad de mucha gente. Aun siendo cierto que, como ha notado Carl Dennis, en el uso del «nosotros» existe un riesgo, puesto que el hablante que se presenta como portavoz de una colectividad «deja a sus lectores preguntándose a cuánto de sí mismo ha debido de renunciar para asumir esa identidad plural» (2001: 12), el acierto con que Jiménez Millán ha sabido recrear ese típico primer vuelo más allá del nido acaba siendo la garantía de que el lector, coetáneo o no, abrace como propia $-\mathrm{O}$ que imagine, cuando menos, como colectiva - la experiencia que le acerca el poema. 
Un referente plural es asimismo el que el siguiente poema parece estar invocando, pero lo curioso es que lo haga sin señalar a nadie en concreto, como un aviso a cualquiera «a quien pueda interesar», y, sobre todo, en un tono cuya sequedad está muy lejos aparentemente de la complacencia que hemos visto propugnada en los tratados. Su autor es el gaditano Felipe Benítez Reyes (2003: 49):

\section{ADVERTENCIA}

Si alguna vez sufres - y lo harás-

por alguien que te amó y que te abandona,

no le guardes rencor ni le perdones:

deforma su memoria el rencoroso

y en amor el perdón es sólo una palabra

que no se aviene nunca a un sentimiento.

Soporta tu dolor en soledad,

porque el merecimiento aun de la adversidad mayor

está justificado si fuiste

desleal a tu conciencia, no apostando

sólo por el amor que te entregaba

su esplendor inocente, sus intocados mundos.

Así que cuando sufras —y lo harás-

por alguien que te amó, procura siempre

acusarte a ti mismo de su olvido

porque fuiste cobarde o quizá fuiste ingrato.

$Y$ aprende que la vida tiene un precio

que no puedes pagar continuamente.

$Y$ aprende dignidad en tu derrota,

agradeciendo a quien te quiso

el regalo fugaz de su hermosura. 
La dimensión apelativa de la composición, del libro Los vanos mundos (1985), aparece clara desde su contundente incipit. Y por un doble motivo: la invocación directa, por supuesto, del tú destinatario, pero también la rotunda autoridad de que se inviste el yo poético por el hecho de revelarse perfecto conocedor de cuál va a ser el destino que corramos. No era difícil, después de todo, jugarse ese farol con semejante mano: nadie ha dejado de llorar, «alguna vez», un desengaño amoroso, un amor que un buen día dejó de hallar correspondencia. Sin apearse de su tono amonestador y severo, el poeta formula a continuación unos consejos que se dirían originales, cuando menos paradójicos, puesto que niegan al contrito receptor sus dos salidas más naturales, aunque opuestas, al conflicto, como son el vituperio y el perdón. Pronto advierte el lector que en el poema no va a encontrar las balsámicas palabras de los manuales de autoayuda, sino más bien el estoico dictado de un nada autoindulgente examen de conciencia, que debe culminar en esa gratitud hacia quien nos acabó desdeñando por «el regalo fugaz de su hermosura». La adopción, en un tal supuesto, de una actitud en principio tan a contrapelo de nuestras reacciones instintivas causa ciertamente sorpresa, pero el poema nos sabe persuadir de que quizá no sea mala forma de superar el trago. De todos modos, ya en una segunda lectura, la reprensión que da cuerpo al discurso acaba por teñirse de camaradería: pocos van a ser los que no perciban, bajo las espartanas protestas que nos hace llegar el yo poético, su condición de víctima de un similar descalabro al que describe, y, por consiguiente, de necesario receptor de esos mismos consejos que nos ha estado dedicando. No se puede dar más de lleno en la diana que cuando Dennis nos dice que, en poesía, sospechamos de quienes se autoproclaman profetas porque queremos que las voces poéticas «nos muestren que no pretenden saberlo todo, que se den cuenta de que todos los esfuerzos por decir la verdad son más bien expresiones de las necesidades particulares de quien se afana en encontrarla que revelaciones de la auténtica naturaleza de las cosas» (2001: 15). Son precisamente esas «necesidades particulares» del yo poético las que terminamos descubriendo, y ello por descontado contribuye, una vez que le sabemos digno de aplicarse la lección que tan riguroso nos impuso, a que cualquier disgusto por su tono de voz desaparezca y le adivinemos al cabo mucho más próximo de lo que al principio habíamos imaginado.

Una reflexión de orden retórico como la que aquí se ha venido alimentando no podía concluir sino al modo en que lo hacen tantas especulaciones particulares propias de esta disciplina. Igual que ocurre cuando después de haber postulado los mejores 
modelos posibles del exordio se reconoce que a veces lo más efectivo es un arranque ex abrupto, igual que ocurre cuando tras inventariar muchas estilizaciones de un enunciado se admite finalmente que su forma más simple y natural tampoco carece de fuerza, aquí también habrá que convenir que, en algunas ocasiones, el admirable mérito de cualquier excepción es acabar confirmando la regla a la que excede. Y es lo que quiero demostrar con el siguiente poema incluido en el libro Los países nocturnos (1996), del valenciano Carlos Marzal. En él, y por paradoja de arte, la escandalosa contravención de todos los principios que hemos ido ilustrando no solamente no aleja al lector del representante de ese impropio y extremado ethos lírico, sino que, si ello es posible, prácticamente le convierte en su cautivo. Veámoslo (1996: 71):

\title{
POR SI NO LO SABÍAS (DEL AUTOR)
}

\author{
Quien escribió estas líneas, \\ el tipo que ha venido \\ con sus huesos a dar en esta página, \\ - por si no lo sabías - no es tu benefactor, \\ no es un filántropo, no tiene compasión \\ por quien ahora le mira más allá de este libro. \\ Conque ni semejante, ni hermano, ni otras estupideces. \\ Tiene un arma en la mano y lo que quiere \\ es descargarla entera en tu cabeza. \\ ( $Y$ eso tampoco significa mucho \\ para él ni para nadie.) Así que ya lo sabes: \\ nunca le des la espalda, \\ no le profeses nunca gratitud. \\ Lo que él quiere de ti sólo es tu miedo, \\ lo que vino a robarte es tu dolor, \\ a cambio del dolor que él ha sentido. \\ Y cuando te lo aprendas será tarde.
}

Quintiliano es, a este respecto, suficientemente claro: «quien, mientras pronuncia su discurso, es tenido por mala persona, habla ciertamente mal, ya que no da 
la impresión de defender algo justo» (1999: 333). Pero, como antes hemos dicho, hay veces que los hechos desmienten a la norma, en particular si es que presentan algún tipo de doblez. Parece que es justo el caso, pues la enunciación del poema no ha podido ser objeto de un más interesado enmascaramiento: el poeta ha hecho como que se ausentaba y nos ha dejado en compañía de una figura anónima que parece hacer las veces de mediador entre los lectores y el responsable de los versos que leemos, al que desde luego todo hace pensar que conoce muy bien. El texto se convierte así en una severa advertencia — al estilo del homónimo poema de Benítez Reyes que leímos antes- en virtud de la cual somos prevenidos del gran peligro que corre cada uno de nosotros si intima demasiado con «el tipo que ha venido / con sus huesos a dar en esta página». Por momentos, el carácter de la confidencia y el signo delictuoso de aquellas acciones de que nos alerta, revisten al poeta del aire de un sicario y a la composición le confieren exactamente, dicho con el término que mejor le corresponde, el valor de un chivatazo. Esta delación, a la postre, tiene como resultado que el lector descubra que ni aquel mal que amenaza con causarle el poeta es del todo gratuito, ni él es la víctima indiscriminada que al azar ha escogido alguien que se comporta como un monstruo. Lo que aquél en realidad busca «de ti es sólo tu miedo, / lo que vino a robarte es tu dolor, / a cambio del dolor que él ha sentido», como se dice en los versos finales, y esta consideración de repente pasa a actuar, por explicarlo de algún modo, como una circunstancia atenuante de aquel crimen anunciado. Justo un momento antes de que sucumbiéramos a la atracción que a veces experimenta la víctima por su inminente verdugo, otros sentimientos han venido a mezclarse, sin embargo, en nuestra respuesta de lectura, y así, a la compasión por quien no persigue sino hallar algún otro dolor a la medida del suyo se superpone enseguida la intuición (reforzada por la relectura del subtítulo del poema) de que la voz que escuchábamos no es otra que la del mismo poeta, cuya defección se ha ocupado de ocultar una tercera persona, en un expediente que sólo ahora estamos en disposición de apreciar hasta qué punto atenúa la posible brutalidad de una declaración directa, y el impudor de ese mismo final si las frases hubiesen estado menos despersonalizadas. ¿No era al cabo Aristóteles, por otra parte, quien recomendaba que «hablase otra persona» cuando fuese embarazoso decir algo a propósito de nosotros mismos? (1418b)

Vueltas las cosas a su derecho sentido, admira entonces la distancia con que Carlos Marzal consigue hablar todavía a favor de un contacto emocional entre lector y 
poeta pero sin tener por ello que caer en las tópicas fraternidades románticas que los versos 4-7 satirizan, en un eco del verso baudelairiano citado en los primeros párrafos de este artículo. La dura imagen del dístico siguiente, con su ráfaga completa de tiros a la cabeza, puede ya ser leída metafóricamente como el deseo de un impacto intelectual sobre el lector, que haga del poema un arma cargada, no de futuro, sino de sentidos, y en el admonitorio verso final cabe ver asimismo una resuelta convicción en el duradero efecto de la palabra poética y en su irresistible capacidad humanizadora y cordial. Una confianza, pues, que es comunicada a los lectores a pesar, como se ha mostrado, del adverso planteamiento del discurso, lo que prueba que hasta el ethos menos complaciente de entre todos los posibles - literalmente, el del poeta asesino- puede también, de forma excepcional, tender su mano abierta al auditorio. Es posible que todo ello tenga bastante que ver con lo que Michael Hamburger escribió en las páginas de su magnífico libro La verdad de la poesía — que puede no ser una desdeñable conclusión a cuanto he dicho-, a propósito de la forma en que los poetas modernos andan dramatizando su voz (1991: 87):

La primera persona de una poesía lírica, ya sea primariamente confesional o primariamente dramática, sirve para expresar un gesto, no para documentar una identidad o para establecer hechos biográficos. Sólo cuando los poetas olvidan esto la primera persona se vuelve «egoísta» y por lo general también aburrida. (...) Como en todas las formas literarias que no sean el verso didáctico desnudo, toca al lector responder al gesto dramático sin saltar al escenario. Difícilmente hay un poeta que valga la pena leer que no pida al lector que entienda y permita «la verdad de las máscaras».

No se me escapa, en conclusión, que un estudio tipológico exhaustivo de todas estas formas retóricas demandaría un espacio muy superior al que ya este artículo ha podido exceder con creces, pero no quería cerrarlo sin antes hacer explícita mi convicción de que sólo aquellos estudios que alleguen en un solo proyecto el análisis formal, elocutivo, a reflexiones como la que se ha intentado desarrollar en estas páginas — más atenta, como se ha visto, a la dimensión pragmática del discurso, a los vínculos que desde el texto consigue establecer su enunciador con quienes van a ser sus definitivos usuarios-, tendrán alguna posibilidad de devolver a la disciplina de la retórica algo de su esplendor pasado, cuando era un pujante programa integrador interesado en el entero proceso de composición y ejecución de los discursos 
persuasivos. Ojalá que esta modesta contribución haya hecho pensar, siquiera por un rato, en la oportunidad de semejantes planteamientos.

\section{REFERENCIAS BIBLIOGRAFICAS}

ARISTÓTELES (1971). Retórica. Trad. de Antonio Tovar. Madrid: Instituto de Estudios Políticos.

Benítez Reyes, F. (2003). Trama de niebla. Poesía reunida 1978-2002. Barcelona: Tusquets.

Cano Ballesta, J. (ed.) (2001). Poesía española reciente (1980-2000). Madrid: Cátedra.

CiCERón (1967). Diálogos del orador. Trad. de Marcelino Menéndez y Pelayo. Buenos Aires: Los Libros del Mirasol.

- (1967 a). El orador. Trad. de A. Tovar y A. R. Bujaldón. Barcelona: Alma Mater.

Corbett, E. P. J. (1990) Classical Rhetoric for the Modern Student. Nueva York y

Oxford: Oxford University Press. ( $1^{\mathrm{a}}$ ed.: 1965)

DenNis, C. (2001). Poetry as Persuasion. Athens y Londres: The University of Georgia Press.

Ferraté, J. (1982). Dinámica de la poesía. Ensayos de explicación, 1952-1966. Barcelona: Seix Barral.

Gallego, V. (2002). Santa deriva. Madrid: Visor.

García Montero, L. (1997). Casi cien poemas. Antología 1980-1995. Madrid: Hiperión.

GIL DE BIEDMA, J. (1993). Retrato del artista en 1956. Barcelona: RBA.

Hamburger, M. (1991). La verdad de la poesía. México: Fondo de Cultura Económica. (1 ${ }^{\mathrm{a}}$ ed. inglesa: 1969).

Isócrates (1980). Discursos. Trad. de Juan Manuel Guzmán Hermida. Madrid: Gredos.

JimÉNEZ MiLlÁN, A. (2003). Inventario del desorden. Madrid: Visor.

Johnson, W. R. (1982). The Idea of Lyric. Lyric Modes in Ancient and Modern Poetry. Berkeley: University of California. 
Machado, A. (1989) Prosas completas (1936-1939), vol. IV de Poesía y prosa. Madrid: Espasa-Calpe y Fundación Antonio Machado.

MARZAL, C. (2001). Metales pesados. Barcelona: Tusquets.

— (1996). Los países nocturnos. Barcelona: Tusquets.

Mesa Toré, J. A. (1999). José Antonio Mesa Toré (Col·lecció «Versos», 19). Lleida:

Edicions de la Universitat de Lleida.

NASH, W. (1989). Rhetoric. The Wit of Persuasion. Oxford: Blackwell.

Perelman, Ch. (1977). L'empire rhétorique. Rhétorique et argumentation. París: Librairie Philosophique J. Vrin, 19973.

Pessoa, F. (1986). Libro del desasosiego de Bernardo Soares. Trad. de Ángel Crespo. Barcelona: Seix Barral.

QUINTILIANO (1999). Sobre la formación del orador, en Obra completa, tomo II (Libros IV-VI). Trad. de Alfonso Ortega Carmona. Salamanca: Publicaciones Universidad Pontificia.

SAlvador, A. (1997). Álvaro Salvador (Col·lecció «Versos», 10). Lleida: Edicions de la Universitat de Lleida.

Salvago, J. (1997). Variaciones y reincidencias (Poesía 1977-1997). Sevilla: Renacimiento. 